\title{
Den langsomme veien er den raskeste
}

\author{
Lillian Grethe Jensen
}

UiT - Norges arktiske universitet

\begin{abstract}
Sammendrag
I denne artikkelen blir historier fra møter med en sangelev i videregående skole brukt som grunnlag for refleksjon rundt temaer knyttet til den brasilianske filosofen og pedagogen Paulo Freires tanker om dialogens betydning i frigjøring av mennesket. Det handler om en bevegelse fra en pedagogikk preget av fremmedgjøring, en pedagogisk praksis der læreren har forutbestemt hva som skal læres og hva utfallet av utdanning skal være, til en pedagogikk der elevens stemme blir hørt. Artikkelen har som mål å belyse hvordan en frigjørende og dialogbasert undervisning kan ha betydning for en elevs utvikling fra passivitet og oppgitthet til aktiv deltakelse. I Freires filosofi og pedagogikk er sann dialog avhengig av kjærlighet, ydmykhet, tro og gjensidig tillit. Disse begrepene er sentrale i artikkelen og brukes i refleksjonen rundt praksishistoriene.

Tittelen henspiller på at den langsomme veien, den tiden det tar å få til en god dialog med en elev, er den raskeste veien til å lykkes.
\end{abstract}

\section{Nøkkelord: Freire; kommunikasjon; frigjørende pedagogikk; tillit; sangundervisning}

\begin{abstract}
In this article, stories from meetings with a young voice student in upper secondary school are used as the basis for reflection on topics related to the Brazilian philosopher and pedagogue Paulo Freire's thoughts on the importance of dialogue in the liberation of man. A movement from a pedagogy characterized by alienation, an educational practice where the teacher has predetermined what to learn and what the outcome of education should be, to an education where the student's voice is heard. The purpose of the article is to illustrate how a liberating and dialogue-based teaching can influence a student's development from passivity and irritation to active participation. In Freire's philosophy and education, true dialogue depends on love, humility, faith and mutual trust. These terms are central to the article and used in the reflection around the practice stories.

The title suggests that the slow road, the time it takes to get a good dialogue with a student, is the fastest way to succeed.
\end{abstract}

Keywords: Freire; communication; liberating education; trust; singing lessons

Received: June, 2017; Accepted: May, 2018; Published: July, 2018

^Korrespondanse: Lillian Grethe Jensen, UiT Norges arktiske universitet, Postboks 6050 Langnes, 9037 Tromsø. Epost: lillian.jensen@uit.no

(C) 2018 L. G. Jensen. This is an Open Access article distributed under the terms of the Creative Commons Attribution 4.0 International License (https://creativecommons.org/licenses/by-nc/4.0/), allowing third parties to copy and redistribute the material in any medium or format and to remix, transform, and build upon the material for any purpose, even commercially, provided the original work is properly cited and states its license.

Citation: L. G. Fensen. "Den langsomme veien er den raskeste». Fournal for Research in Arts and Sports Education, Special Issue: "Skapende og tenkende - Perspektiver på kritisk kunstpedagogikk i skole og kulturliv" Vol. 2(2), 2018, pp. 75-86. http://dx.doi.org/10.23865/jased.v2.923 75 
«Wow... dette har jeg aldri kjent for!» en sangelev.

\section{Innledning}

Vi lever i en utålmodig tid, skriver Gert J. J. Biesta i sin bok Utdanningens vidunderlige risiko (Biesta, 2014). En tid der vi hele tiden eksponeres for ideen om at umiddelbar tilfredsstillelse er mulig. Denne utålmodigheten finnes ikke bare hos individet som raskest mulig ønsker å mestre, forstå og innfri, men også som en forventning $\mathrm{i}$ utdanningssystemet.

Biesta setter fokus på et tema som har blitt viktig for meg i min pedagogiske virksomhet. Han sier blant annet at man bør spørre seg om hva man vil oppnå med å utdanne mennesker, og i hvilken grad det er mulig å forutbestemme utfallet. Han fokuserer på undervisning som «[...] ikke tilstreber tilpasning, men som snarere tilbyr motstand, ved å forstyrre og utfordre» (Biesta, 2014, s.17). Med en slik type tilnærming tror jeg man kan oppnå at elevene blir aktive og kritiske deltakere i læringsprosessen. Mitt spørsmål er hvordan man i sangundervisning kan fremme en aktiv, reflektert og deltakende innstilling hos elevene.

\section{Møtet med den brasilianske filosofen og pedagogen Paulo Freire}

I denne artikkelen blir Paulo Freires (2011) filosofi om dialogens betydning i frigjøring av mennesket min medspiller. Jeg ønsker å bruke hans ideer i refleksjonen rundt min egen praksis som sangpedagog. Møtet mellom meg som subjekt og Freires tekst skaper den meningen jeg vil formidle. Freires filosofi om frigjøring gjennom dialog møter min erfaring.

Interessen for dette temaet kan føres tilbake til møter jeg har hatt med mange ulike pedagoger og de utallige undervisningssituasjoner jeg har vært en del av. I disse møtene og situasjonene har jeg hatt ulike roller og ulik grad av opplevelse av å kunne bidra. Som elev har jeg ofte opplevd at jeg har hatt begrenset eller ingen mulighet til å påvirke innholdet og formen på undervisningen, mens jeg som pedagog har erfart at man kommer til kort hvis man ikke får til en god dialog med eleven.

I artikkelen vil jeg bruke et møte med en elev i videregående skole som grunnlag for refleksjon rundt temaer knyttet til Freires teorier om dialog og frigjørende pedagogikk. Navnet til eleven er fiktivt, og hendelsene er satt sammen av ulike elevmøter, men jeg har valg å fortelle historien gjennom én elev som har fått navnet Ida. Historiene er ikke basert på systematisk innsamlet materiale, men bygger på faktiske hendelser fra min egen undervisning. Utvalget av historier er gjort fra situasjoner der jeg som lærer har blitt utfordret i møte med sangelever jeg har opplevd som umotiverte og initiativløse.

\section{Å undervise i musikk}

Musikere og musikkpedagoger blir stadig utfordret i møte med krav til selvstendighet, kreativitet og fleksibilitet knyttet til egen praksis, både som utøvere og pedagoger. 
De samme kravene er noen av de betingelsene for kvalitet som legges til grunn for å få en god bedømming på en eksamensprestasjon. Det å utdanne mennesker som er i stand til å skape sin egen arbeidsplass og ha et unikt kunstnerisk uttrykk, er noe de fleste av utdanningsinstitusjonene innenfor utøvende musikkutdanning er opptatt av. Denne virkeligheten gjenspeiler seg også i strategiplanen til det kunstfaglige fakultet ved UiT - Norges arktiske universitet, der jeg er ansatt:

Kunst og kulturuttrykk treffer dypt og berører bredt. Kunst preger oss og gir grobunn for refleksjon. Kunstnere og kunstformidlere tiltrekker seg offentlig oppmerksomhet, skaper debatt og flytter grenser.

Kunst- og kulturfeltet trenger derfor selvstendige og trygge utøvere og pedagoger som har evne og vilje til å bidra til utvikling og endring innenfor sine fagfelt. [... $]^{1}$

I min virksomhet som sangpedagog møter jeg elever ${ }^{2}$ i forskjellige aldere og på ulike ferdighetsnivå. De aller fleste er elever i videregående skole eller ved høyere utdanningsinstitusjoner. Elevene søker til disse utdanningene fordi de har ønsker og forventninger til det å spille og synge, og de håper kanskje å kunne leve av musikken.

Selv om jeg i de fleste tilfeller representerer utdanningsinstitusjonen, skal denne artikkelen ikke handle om læringsmål fra emneplaner og studieplaner, men om hvordan jeg som pedagog tenker og virker i møtet med de som kommer til meg for å få undervisning i sang og stemmebruk. Selvfølgelig vil jeg at eleven skal gjøre det godt, klare sine eksamener og lykkes som utøver etter endt utdanning, men veien dit blir rikere og mer spennende hvis man tar sjansen på å stå i det åpne. Å stå i det åpne innebærer at jeg må forholde meg til eleven som et subjekt, som noe enestående, og eleven må være åpen og kritisk til den undervisningen jeg som lærer kan gi. Hva utfallet av undervisningen blir, kan hverken jeg eller eleven være sikker på. Å stå i det åpne er etter min mening en nødvendighet fordi vi i utdanningene har å gjøre med levende mennesker. I undervisningsprosessen må jeg ta et skritt tilbake slik at eleven kan få mulighet til å ha en aktiv rolle. Min holdning er at jeg i stedet for å ha bestemt på forhånd hvor vi skal starte og hvor vi skal ende, forsøker å finne ut hvor eleven er og hvor han eller hun vil.

\section{Møtet med Ida}

Ida er ei jente på 18 år. Hun er elev $i$ tredje klasse på musikklinja $i$ videregående skole. Om 10 måneder skal hun ha sin eksamen $i$ sang. Tida frem til primo juni er knapp, og veien vi skal gå føles lang. Dette tenker jeg etter at jeg har blitt informert om hennes progresjon og medvirkning $i$ musikkfagene så langt. Jeg tenker også det når jeg møter henne første og andre gang, men da på en litt annen måte. Den informasjonen jeg har fått om henne, er at hun

${ }^{1}$ https://uit.no/om/enhet/forsiden?p_dimension_id=88173 (hentet 10.01 .2018 )

${ }^{2} \mathrm{Når}$ jeg bruker ordet elev, referer jeg i denne artikkelen både til elever i den videregående skolen og studenter i høyere utdanning. 
ikke har deltatt $i$ samspill med sine medelever, og at hun trekker seg unna. Hvorfor hun ikke har deltatt, eller hvorfor hun trekker seg unna, vet jeg ikke.

I møte med henne ser jeg ei jente som er svart opptatt av å gjøre de «riktige tingene», og ei jente som er svart selvkritisk. Vennlig og lyttende skriver hun ned alt jeg sier i loggen som eleven ifølge lareplanen er pålagt å lage. Hun er ei smart jente som er redd for å dumme seg ut - og som har bestemt seg for at hun sanglig ikke er god nok. "feg synger stygt og surt», sier hun. Jeg spør henne hva hun vil at vi skal begynne å jobbe med, om hun har noe repertoar hun tidligere har jobbet med som hun vil ta videre? Etter mange runder med samtaler rundt repertoarvalg, sier hun hva hun ikke liker av det hun har jobbet med tidligere, og det er mye. Til slutt kommer hun med noen forslag til artister hun liker, og vi lytter til sanger som kan vare aktuelle å jobbe med. Vi kommer godt $i$ gang, men når jeg spør henne om det er noen $i$ klassen hun vil spille sammen med, blir hun usikker. Feg sier til henne at jeg tror dette kan bli fint. Hun takker, men jeg ser $i$ øynene hennes at hun er skeptisk til om jeg mener det jeg sier.

\section{Dialog og frigjørende pedagogikk}

Freires teori og metode bygger på at folk gjennom dialog kan bli aktive og kritiske, vinne selvtillit og utvikle ny kunnskap. Dialogisk handlingsteori (Freire, 2011) som inspirasjonskilde for samarbeid fordrer samtale og tar utgangspunkt i det som er viktig for den som defineres som elev. Dialogens intensjon er å fremme bevisstgjøring og kritikk, avdekke og forskyve makt og må lede til praktisk handling. Slik jeg leser Freire, er ingen læringsprosess nøytral, men representerer enten en tilpasning eller en oppdragelse til selvstendighet.

Frigjørende pedagogikk kan ikke skje uten kommunikasjon, og kommunikasjon er avhengig av at det finnes dialog (Freire, 2011). Kommunikasjon må ikke her forstås som et forhold der læreren forteller og eleven er en passiv mottaker, men som en situasjon preget av mening og tolkning.

For Freire var det viktig at lærernes livsdrepende fortellinger ble erstattet av oppriktig dialog. Gjennom dialog er det ikke lenger snakk om «at dette er mine elever» eller at «dette er mine lærere» (Steinsholt, 2004, s. 600).

Gjennom en slik dialogisk tilnærming i undervisningen kan lærer og elev komme frem til en felles forståelse av det undervisningen til enhver tid handler om.

«En første forutsetning for at et menneske kan delta er at en ikke er utrygg, passivisert og undertrykt» (Freire, 2011, s. 13). Freire hevder at de undertryktes kultur og tenkning er preget av fremmedgjøring, og den representerer ikke den virkeligheten de undertrykte lever i. Jeg tolker dette som at en pedagog som i sin undervisning ikke tar hensyn til den virkeligheten eleven lever i, men heller jobber for å spre sine teorier, kunnskaper, verdier og tradisjoner, vil fremstå som undertrykkende. «Slike misjoneringspedagoger vil omdanne elevene til «objekter» som de kan manipulere og styre dit de selv ønsker» (Steinsholt, 2004, s. 591). 
Pedagogikk som skal bidra til vekst og utvikling, forutsetter at det legges til rette for at eleven skal kjenne seg som en likeverdig deltaker i et fellesskap. Eleven må være sikret veiledning og støtte til å bygge opp identitet og selvaktelse og bli møtt med tillit og forventning (Freire, 2011).

\section{Instrumentalundervisning og frigjørende pedagogikk}

En av de sentrale ideene når det gjelder frigjørende pedagogikk, er at folk får tilstrekkelig innsikt i maktrelasjonene som har betydning for deres situasjon.

Slik jeg forstår dette, handler denne frigjøringen om en bevegelse bort fra en naivitet der man ikke er i stand til å se hvordan man kan påvirke den verden man lever i, og mot kritisk bevissthet: en bevissthet om at det er mulig å gripe fatt i utfordringer, søke løsninger og innsikt (Steinsholt, 2004).

Overfører man denne tenkningen til instrumentalundervisning, kan man peke på flere faktorer som kan skape asymmetri og virke fremmedgjørende. Forholdet mellom lærer og elev, mellom elev og instrument og mellom eleven og den musikken han eller hun beskjeftiger seg med, er noen.

I sangundervisningen har vi en lang tradisjon for at pedagogens praksis har vært «hemmelig» og knyttet til fornemmelser, følelser og mystikk, og der mye av undervisningen har vært preget av såkalt blomsterspråk. Blomsterspråk er en måte å snakke på der man bruker metaforer og anekdoter i arbeidet med å få eleven til å forstå og utvikle ferdigheter på instrumentet. I sin bok Om sangpedagogikk henviser Sissel Høyem Aune til en praksis der «Teknisk arbeid gikk etter intuisjon, etter følelse, mange ganger mer etter lærerens følelser enn etter elevens. Undervisningsspråket var rikt på metaforer» (Aune, 2003, s. 15).

Hvis eleven ikke klarer å overføre disse bildene eller historiene til ønskelig utøving, blir det elevens problem. I en slik situasjon går kanskje eleven fra undervisningen med en følelse av ikke å forstå eller mestre. For at metaforer skal ha en funksjon, må de som skal bruke disse bildene ha felles referanser. Redselen for å ta bort mystikken og kunsten har ført til at mange sangpedagoger har kviet seg for å nærme seg faget fra en mer vitenskapelig synsvinkel (Aune, 2003). Pedagogens språk er altså knyttet til hennes/hans forståelse. En situasjon der læreren, eller mesteren, sitter på svarene, mens eleven fremstår som uvitende og trenger opplæring, forstår jeg, i Freires terminologi, som en undertrykkende pedagogikk: en pedagogikk som tar sikte på å temme og forme eleven framfor å frigjøre. Dette har nok tradisjonelt vært en gjensidig forståelse der læreren har sett seg selv som innehaver av sannhetene, og eleven har forventet at læreren skal overføre sin kunnskap og ferdighet. Nå kan det høres ut som om dette forholdet er historisk og uaktuelt i dagens skole, men det mener jeg ikke. Disse holdningene og praksisene finnes også i dag, både blant elever og lærere. «Når elevene ser seg selv som tomme gjenstander som skal fylles av lærernes pondus og autoritet, betrakter de seg selv som passive, og passive elever er det lett å kontrollere, dressere og manipulere» (Steinsholt, 2004, s. 598). Eksempelvis kan det å sette seg inn i instrumentets anatomi og virkemåte være nyttig for å forstå muligheter og 


\section{G. Fensen}

begrensninger. Med økt kunnskap og forståelse gis eleven mulighet til å delta aktivt $i$ å løse stemmemessige utfordringer. Det finnes etter hvert mange bøker og metoder som tar sikte på å gi verktøy til mennesker som ønsker å bli bedre utøvere i sang, deriblant teknikker og metoder som har som mål å bidra til at utøvere får større trygghet og kontroll over sitt instrument. Oren Brown, ${ }^{3}$ Estill Voice Training (EVT) ${ }^{4}$ og Complete Vocal Technique (CVT) ${ }^{5}$ representerer noen av disse metodene. Selv metoder og teknikker som har til hensikt å bidra til at sangere skal få bedre kontroll over instrumentet, kan komme i fare for å bli fremstilt som autoriteter som sitter på de eneste riktige svarene. Det jeg mener, er at man må være bevisst og stille spørsmål til om i hvilken grad man som representant for en spesiell skole eller teknikk er i stand til å stille seg åpen og være i dialog med den enkelte elev.

\section{Dialog}

Å være i dialog, eller å ha en dialogbasert undervisning, handler ikke bare om møtet mellom lærer og elev, men om det man vil føre en dialog om. «[...] å være opptatt av innholdet av en dialog er virkelig å være opptatt med det som burde være undervisningens innhold» (Freire, 2011, s. 77).

Freires dialog står for meg som et tillitsfullt møte hvor deltakerne gjennom refleksjon og handling kommer frem til ny kunnskap og forståelse. «[...] lærer og elev møtes i felles «temaer», som de kan "sam-undersøke». En slik undersøkelse må være kritisk ved at den ikke er partikulær, men søker å forstå sammenhenger og helheter» (Freire i Kristiansen, 2014, s. 107). I diskusjonen eller sam-undersøkelsen respekterer man hverandres ulikheter.

Når jeg snakker om dialog og om å være sam-undersøker, betyr det ikke at jeg, som Biesta (2014) sier, kun er en tilrettelegger. Han sier det slik:

[...] som motsvar til ideen om læreren som en med-lærende eller tilrettelegger for læring fremsetter jeg at læreren må betraktes som en som på helt generelt grunnlag bringer inn noe nytt i den pedagogiske situasjonen, noe som ikke var der fra før. Derfor vil jeg hevde at undervisning ikke kan være helt og fullt noe som ligger i den pedagogiske situasjonen, men forutsetter en forestilling om transcendens (Biesta, 2014, s. 68).

Jeg forstår Freire og hans dialog dithen at læreren er mer enn en tilrettelegger i pedagogiske situasjoner. Læreren er også en aktiv deltaker i dialogen og bringer inn sin kunnskap, erfaring og kompetanse. Læreren har med seg noe som eleven ikke har, men må behandle eleven med anerkjennelse, tro, tillit og kjærlighet. Det handler om hvilket syn man har på hva undervisning skal være, på pedagogisk vurderingsevne og på hvilken rolle læreren har i samspill med eleven.

\footnotetext{
${ }^{3}$ En amerikansk pedagog som har utgitt boken «Discover Your Voice».

${ }^{4}$ Et system utviklet av den amerikanske stemmeforskeren Jo Estill.

${ }^{5}$ En teknikk utviklet av den danske sangeren og pedagogen Cathrine Sadolin.
} 
Dialogen med sitt utspring i kjærlighet, ydmykhet og tro blir et horisontalt forhold der gjensidig tillit mellom de samtalende er den logiske konsekvens. Det ville være en selvmotsigelse om dialogen - kjærlig, ydmyk og full av tro - ikke skapte denne atmosfære (Freire, 2011, s. 75).

Biesta (2014) trekker også frem at utdanning handler om mellommenneskelig samspill, og ikke primært om et samspill mellom mennesker og den materielle verden. Han sier at vi som pedagoger hverken kan eller vil «påstå at vi produserer våre elever. Vi utdanner dem, vi utdanner dem i frihet og for frihet» (s. 62). Når jeg leser Freires tekster om dialogen, forstår jeg at en sann dialog først er mulig når møtene mellom deltakerne preges av kjærlighet, håp og forventning, tro og tillit. Jeg har erfart at dette er en fruktbar, men også en langsom vei. Å oppnå et gjensidig forhold som preges av alle de forholdene Freires dialog fordrer, krever tid og tålmodighet.

\section{Kjærlighet}

feg spør Ida om hun alltid har vert misfornøyd med stemmen og sangen sin. Første gang jeg tar opp dette temaet, svarer hun ja på spørsmålet, men etter en tid forteller hun meg at det var noe hun kom frem til da hun begynte på videregående. "Det er så mange flinke her», sier hun.Vi snakker om at det selvfølgelig er mange som er veldig flinke, men at hun også har noe å fare med. Hun er tvilende, men er ikke lenger bare unnvikende, hun møter meg. Vi snakker om nervøsitet og prestasjonsforberedelse. Hun sier at hun forstår det med hodet, men det hjelper lite når kroppen ikke er enig.Vi snakker om mot, og om det å øve seg på å mestre vanskelige situasjoner. Feg sier til henne at jeg synes hun er modig som til tross for at hun er livredd for å stå foran andre og synge, likevel gjør det. «Synes du det», sier hun, og blir litt stolt av seg selv.

Etter hvert åpner hun seg mer, og hun viser også at hun tør å bruke stemmen mer dynamisk og utforske ulike stemmeuttrykk. Hun tar mer ansvar og initiativ $i$ arbeidet.

I timene med Ida er jeg opptatt av å vende det noe destruktive synet hun har på seg selv i forhold til det å synge, til noe konstruktivt. Hvorfor har hun valgt å ta musikkutdanning når hun ikke liker å fremføre musikk for andre? Har hun alltid hatt en negativ holdning til seg selv og sin stemme? Har hun tidligere sunget på konsert? Er det noen settinger hun ville vært komfortabel med å fremføre noe i?

De første gangene jeg kommer inn på denne tematikken, er svaret på det andre spørsmålet ja, og hun vil egentlig ikke snakke om dette. Senere kommer det frem at hun har sunget mye offentlig; det var etter at hun begynte på videregående at hun oppdaget at hun ikke hadde "noe fin stemme", og at hun ikke var flink nok. Hun sammenlignet seg med medelevene og mestret ikke de øvelsene og de utfordringene hun fikk hos sine lærere. Hun var ikke god nok! Det at hun deler dette med meg, er en spire til en dialog. Hun innvier meg i noe hun føler hun har tapt, og jeg forstår mer av hvorfor hun ønsket å gå på denne skolen.

En ekte dialog fordrer at deltakerne møter hverandre med kjærlighet (Freire, 2011). Dette høres kanskje enkelt og klisjeaktig ut, men hvis man forstår hva som 
ligger bak ordet kjærlighet, vil man forstå hvorfor Freire legger dette frem som premiss.

In his work, P. Freire (...) spoke of love for his students, but always in relation to teaching. «When I say to love I mean to love the very process of teaching». (Darder, 2015, s. 55)

Kjærlighet handler om å møte mennesker med respekt og anerkjennelse. Å respektere og anerkjenne handler om å ta et annet menneske på alvor, å forsøke å forstå gjennom oppriktig interesse. "Å ta den andre alvorleg er det same som å vera viljug til å ta hans meiningar opp til ettertanke, eventuelt diskusjon» (Skjervheim, 1976, s. 55 ff).

I sin bok Freire and Education (2015) sier Antonia Darder at når Freire snakker om kjærlighet, er det ikke bare snakk om å «dulle» med de fattige for å gjøre livet enklere. Freire ser ikke kjærlighet som et konsept som kun skal fungere som trøst og lindring, men også som en hjelp til å vekke den kritiske bevisstheten. Darder (2015) sier at Freire ser på kjærlighet som en kraft til politisk og pedagogisk oppvåkning.

Freire's love permeated his existence as a man and an educator. He could be gentle, tender, and inspiring, while at the same time, critical, challenging, and strategic in unveiling individual or collective follies (Darder, 2015, s. 48).

I Freires filosofi blir det å vise ydmykhet i møte med eleven viktig. Man må i undervisningssituasjonen ha en ydmyk holdning til det arbeidet man skal gjøre sammen med elevene. For meg henger kjærlighet og ydmykhet sammen. Jeg må møte det andre mennesket med en visshet om at han eller hun har med seg noe inn i situasjonene som vil påvirke deres forståelse av det vi skal jobbe med. Det er som jeg tidligere har sagt, et møte mellom levende mennesker, et møte jeg som pedagog må gå inn i med bevissthet om at jeg kan bidra med noe, men også innse at jeg har mangler og svak heter. Disse manglene handler om at jeg ikke kan kjenne et annet menneske fullt ut, og dermed ikke forutsi hvordan han eller hun vil forstå eller gjøre bruk av min undervisning. Det kan imidlertid også handle om mangler i forhold til det vi samarbeider om:

Ida har funnet en sang som hun vil jobbe med.Vi har snakket om ulike innstuderingsmetoder, og hun har jobbet med teksten. Det er en engelsk tekst som hun har oversatt og tolket. Hun opplever melodien som rolig og litt vemodig, og teksten underbygger denne stemningen. Dette er en sang jeg også har et forhold til, men jeg har en helt annen forståelse av teksten enn henne. feg tenker at den er mørkere og mer dyster enn det Ida ønsker å formidle.Vi leser teksten forskjellig, vi tolker den ut fra vår erfaring, og det påvirker det uttrykket hver av oss vil gi den.

Når vi snakker om dette, er hennes forståelse av sangen like viktig som min. Jeg kan kanskje noe om dikterens bakgrunn og den tiden teksten ble skrevet $i$, og det kan jeg formidle til henne. På den måten kan jeg gi henne flere knagger å henge en tolkning på, i tillegg til at jeg kan anbefale henne å lytte til ulike innspillinger av sangen. Jeg kan gjennom min undervisning gi henne kunnskap og inspirasjon, men til sist er det hennes forståelse som ligger til grunn for hvordan hun velger å tolke teksten og sangen. 


\section{Tillit}

Hva vil du jobbe med? spør jeg Ida. Hun sier at hun gjerne vil synge en rolig jazzballade. feg sier at jeg synes det er en god idé, og at vi begge kan komme med forslag til sanger neste time. Når vi møtes igjen, er det vi avtalte forrige time helt ute av hodet mitt. Derfor starter jeg timen med å spørre henne hva hun vil jobbe med. Hun minner meg på hva vi avtalte forrige time og viser meg noen forslag til jazzlåter. Feg må innrømme at jeg har glemt avtalen, men sier at det er fint at hun har husket på å finne låter.

Dette er et enkelt, men godt eksempel på hvordan mangel på samsvar mellom ord og handling kan ødelegge et tillitsforhold. Når jeg spør om hennes mening og gir inntrykk av at jeg synes hennes forslag er gode, for så å glemme det til neste møte, kan hun oppfatte mitt engasjement som uekte. Jeg vet at Ida er tilbakeholden og at hun har lite tro på seg selv i forhold til sangfaget. Det at hun har begynt å åpne seg for meg, må jeg ta vare på. Hun må ikke begynne å tvile på min oppriktighet når jeg sier at jeg vil høre hennes mening og at hennes bidrag til egen utvikling er viktig.

For Freire (2011) er mangel på tillit også et manglende grunnlag for dialog. Mislykkes man i å skape et tillitsforhold, er det grunnet $\mathrm{i}$ at forutsetningen for å skape tillit mangler. Jeg må ha tillit til at Ida gjør det vi har avtalt, og samtidig ha forventning til at hun klarer det. På samme måte skal hun kunne ha forventning og tillit til at jeg følger opp og viser engasjement $i$ arbeidet med å hjelpe henne videre.

Tillit handler også om å ha tillit til seg selv og til at det man formidler blir tatt imot med anerkjennelse. Når jeg første gang spør Ida om hva hun ønsker å få ut av sangundervisningen og om hvilke sanger hun liker, sier hun at hun ikke vet. Hun har det kanskje ikke så klart for seg, eller så synes hun det er litt skummelt å si høyt det hun ønsker seg og håper på. Hvordan vil det bli tatt imot? Tiri Bergesen Schei (2007) tar i sin avhandling opp identitetsspørsmålet: «Å søke identitet er handlinger som uttrykker individets drømmer og ønsket fremtid. Hva slags retning livet skal ta, hvem man ønsker å fremstå som» (Schei, 2007, s. 186). Schei problematiserer faktorer som virker hemmende på tanke og handling. I en Freiretradisjon ønsker man å skape et læringsmiljø som vektlegger trygghet, og som på den måten virker frigjørende.

[...] one of the most important tasks of a pedagogy of love is to create the conditions for students to engage in the experience of assuming themselves as social, historical, thinking, communicating, transformative, creative persons; dreamers of possible utopias, capable of being angry because of a capacity to love (Freire i Darder, 2015, s. $53 \mathrm{ff}$ )

I sangfaget møter Ida på normer og regler fra faglærere, medelever og fagplaner. Hun speiler seg i reaksjoner hun får på sine handlinger. Motivasjon for å jobbe fremmes eller hemmes i forhold til hvor stor tiltro hun har til det hun gjør. Min rolle som pedagog er å hjelpe henne slik at vektskåla ikke blir for tung mot det som hemmer, og å bidra til at hun blir styrket og selvstendig. 
Etter å ha jobbet med Ida en stund, har jeg begynt å forstå hva hun liker å jobbe med og hva hun trenger å øve på for å få mer kontroll over stemmen. Ut fra denne forståelsen gir jeg henne en sang som jeg vil at hun skal se på. Når hun kommer til neste time, spør jeg henne hva hun synes om sangen og om hvordan hun har jobbet med den. Hun sier at hun liker den og at hun har lyttet til noen innspillinger med versjoner av sanger som hun liker. Hun vil gjerne jobbe med den.

Håp er knyttet til en forventning om at man skal kunne oppnå noe gjennom sitt arbeid. I en utdanningssituasjon vil man ha forventning om utvikling og endring. Slik jeg tolker Freire, vil møte mellom lærer og elev der situasjonen oppleves som håpløs, være demotiverende og kjedelig. En situasjon der partene ikke forventer seg noe, skaper ingen «drive».

Hvis jeg i møte med Ida istedenfor å spørre hva hun syntes om sangen og hvordan hun har jobbet med den, hadde spurt om hun hadde sett på sangen, hadde jeg signalisert at jeg ikke forventet noen innsats fra henne. Når jeg spør om hvordan hun har jobbet og hva hun synes om sangen, ligger det implisitt at jeg forventer meg noe av henne. Slik jeg leser Freire, er ikke forventningen knyttet til en person, men til resultatet av en persons handling. Gjennom arbeid sammen med meg på timene, og gjennom egen øving, håper og forventer både Ida og jeg at hun skal få økt forståelse og forbedrede tekniske og musikalske ferdigheter.

\section{Den langsomme veien er den raskeste}

I denne artikkelen har jeg snakket om hvordan jeg jobber for å ha en dialogbasert tilnærming til sangundervisning. Som lærer har jeg erfaring, kunnskap og ferdigheter som eleven kommer for å få en del av. Når jeg ønsker å fremme en praksis der man gjennom handling og refleksjon kommer fram til ny kunnskap og forståelse, må jeg ha elevens eller studentens anerkjennelse for denne måten å tenke på.

I mange tilfeller er det jeg som har bestemt at undervisningen skal være dialogbasert. Det er jeg som krever at eleven skal engasjere seg - være aktiv. Å være aktiv handler for meg om å ta stilling til, undersøke, tolke, mene noe om hvordan en sang vi jobber med kan fremføres, øve og stille spørsmål til øvelser, jobbe så mye med noe at man blir engasjert, våge å gjøre valg og diskutere. Noen elever synes nok at det er plagsomt og at det tar for lang tid. Hadde det ikke vært kjappere å bare gi noen øvelser, fortelle hva som er rett, gi fasit? Dialog fordrer at man er med frivillig, men er eleven eller studenten med på dette frivillig?

Jeg har tidligere sitert Biesta (2014), som setter fokus på hva formålet med utdanning skal være. Hvis formålet med utdanningen er «å utdanne selvstendige og trygge utøvere og pedagoger som har evne og vilje til å bidra til utvikling og endring innenfor sine fagfelt $[\ldots] \|^{6}$, må vi bidra til det gjennom våre studieplaner og vår undervisning.

${ }^{6}$ https://uit.no/om/enhet/forsiden?p_dimension_id=88173 (Hentet 10.01.2018) 
Jeg tror det er vanskelig å nå dette målet uten at eleven eller studenten er aktivt med. Her vil jeg igjen trekke frem Freires (2011) teori og metode som bygger på at folk gjennom dialog kan bli aktive og kritiske, vinne selvtillit og utvikle ny kunnskap.

Jeg er overbevist om at det ligger en fare for fremmedgjøring og passivitet i ukritisk å reprodusere det andre har gjort, eller det andre mener du skal giøre. Du blir fremmed for det du gjør fordi du ikke har fătt eller har benyttet anledningen til å bidra. Fremmedgjøring kan føre til uro og usikkerhet, og passivitet fører til at du forventer at noen skal lære deg det du trenger å vite for å lykkes. Det jeg som lærer kan bidra med, er å dele min kunnskap og gi eleven eller studenten redskaper til selv å løse problemer og finne nye veier. Undervisningen blir ikke en enveiskommunikasjon der lærere «mater» eleven, men et sted der lærer og elev i samarbeid utforsker og skaper nye uttrykk og meninger.

Ida skal ha sin eksamen. Feg vil gierne at hun skal ha en fin opplevelse, selv om hun gruer seg til dette. Denne seansen har vi snakket om mange ganger, og Ida snakker om dette som et nødvendig onde. Hun vil gjennomføre prøven, men er sikker på at det ikke kommer til å gå bra-det kommer til à bli en dårlig opplevelse. Feg spør om hun vil sette et dempet konsertlys og invitere publikum, men det gjør henne bare mer nervøs.

Når det er hennes tur, har hun allikevel bestemt seg for å ha dempet konsertbelysning, og hun inviterer hele klassen i tillegg til familien sin til a vere til stede som publikum.

Etterpå spør jeg hvordan hun opplevde eksamenskonserten, og hun sier at det kjentes kjempebra og at hun er veldig fornøyd. Hun er fornøyd med at hun våget å ha publikum tilstede, og at hun mestret det. Hun valgte det selv, og hun tålte det. Karakteren ble bra, men det var ikke det hun var opptatt av. Det at hun gjorde et valg og mestret situasjonen, var en seier.

Da jeg første gang møtte Ida, ville hun ikke si hva hun likte - hun likte alt, hørte på alt. Men det gjorde hun slett ikke, hun stolte bare ikke på at det hun likte og ønsket å jobbe med var bra nok. Jeg tror ethvert menneske ønsker å påvirke sin egen virkelighet, selv om det kan virke som om de ikke vil ta stilling til spørsmål som direkte påvirker deres hverdag og fremtid. Fortellingen om undervisningssituasjonene sammen med Ida illustrerer eksempler på tilnærming til en frigjørende og dialogbasert undervisning som kan ha betydning for en elevs utvikling fra passivitet og oppgitthet til aktiv deltakelse. Noen vil kanskje spørre om vi har tid til denne måten å drive undervisning på, men jeg tror ikke vi kan drive god undervisning uten å være i dialog med elevene. "The pace of modern life, the need to understand almost instantly, can seriously damage our chances of understanding anything properly.» (Fletcher i Hamilton, 1990, s. IX). Jeg tror at den langsomme veien, den tiden det tar å få til en god dialog med en elev, kan være den raskeste veien til kunnskap og innsikt.

\section{Forfatteromtale}

Lillian Grethe Jensen er universitetslektor i sang og faggruppeleder ved Musikkonservatoriet, Det kunstfaglige fakultet, UiT Norges arktiske universitet. Hun er 
utdannet faglærer i musikk fra Nordnorsk musikkonservatorium, og har hovedfag i musikkvitenskap fra Norges teknisk-naturvitenskapelige universitet - NTNU. Hun har vært mye brukt som stemmepedagog ved norske teater, og har i en årrekke undervist i sang på forskjellige nivåer. Hun er særlig opptatt av å jobbe med ulike vokalteknikker og didaktikk.

\section{Litteratur}

Aune, S. H. (2003). Om sangpedagogikk. Trondheim: Tapir Akademisk Forlag. Biesta, G. J. J. (2014). Utdanningens vidunderlige risiko. Bergen: Fagbokforlaget. Darder, A. (2015). Freire and Education. New York: Routledge.

Freire, P. (2011). De undertryktes pedagogikk. Oslo: Gyldendal Norsk Forlag.

Hamilton, D. (1990). Learning about Education. Philadelphia: Open University Press.

Kristiansen, A. (2014). Rom for anerkjennelse $i$ utdanningssystemet. Bergen: Fagbokforlaget.

Schei, T. B. (2007). Vokal identitet: En diskursteoretisk analyse av profesjonelle sangers identitetsdannelse. Bergen: Universitetet i Bergen.

Skjervheim, H. (1976). Deltakar og tilskodar og andre essays. Oslo: Tanum-Norli.

Steinsholt, K. (2004). "Paulo Freire: Håpets pedagogikk». I K. Steinsholt \& L. Løvlie (Red.). Pedagogikkens mange ansikter (s. 587-601). Oslo: Universitetsforlaget.

The publication charges for this article have been funded by a grant from the publication fund of UiT The Arctic University of Norway 